\title{
Identification of Residual Stresses in a Surface Layer of Ti6AL4V and Inconel 718 after Process of Peripheral Milling
}

\author{
Joanna KRAJEWSKA-ŚPIEWAK, Józef GAWLIK, Witold PIEKOSZEWSKI, Krzysztof STACHURA
}

\begin{abstract}
Titanium based alloy - Ti6AI4V and nickel based alloy - Inconel 718 belong to the group of difficult-to-cut materials. Thanks to their unique properties they can be used in constructions that need to withstand the high reliability requirements which are required inter alia in the aircraft industry. The physical properties of cutting layer, including residual stresses, play an important role during exploitation of products made out of difficult-to-cut materials. In the article, the method of residual stresses determination is described and the exemplary results of carried out studies are provided. Described method is based on the measurement of the defects in the crystal lattice. The carried out studies show that the state of residual stresses, in a subsurface layer, can be formed by the selection of machining conditions.
\end{abstract}

Keywords: difficult-to-cut materials; milling; residual stresses; subsurface layer; $x$-ray diffraction

\section{CRYSTALLOGRAPHIC STRUCTURE OF Ti6AI4V AND INCONEL 718 (INTRODUCTION)}

Currently, the construction materials such as titanium based alloys are the most important and most commonly used in aircraft industry. Unique properties enable them to work under variable load through which variable stress values are generated. Studies show that elements submitted to variable loads can be destroyed under significantly lower stresses than statically overloaded elements. Processes through which workpiece is destroyed due to the variable load (stresses) are called fatigue [1]. As a result of fatigue decohesion of material appears, which is caused by emerging defects (inclusions, crack propagation) under variable load.
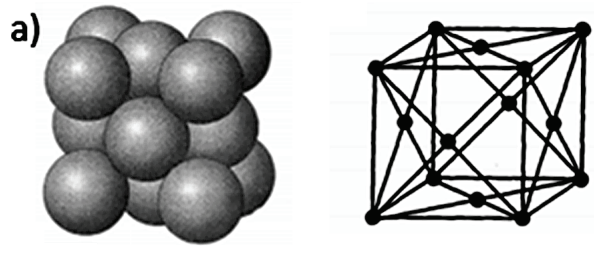

b)
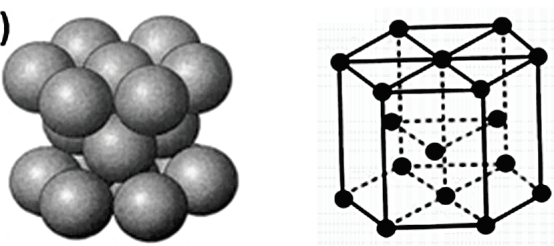

Figure 1 Crystal structure a) faced cantered cubic structure (A1), b) Hexagonal close packed structure (A3)

Both, titanium based alloys and nickel based alloys, have polycrystalline construction which is characterized by a large amount of crystals (grains, crystallites). Usually, grains are differently oriented (directedness), which means the material has isotropic properties as opposed to materials that show anisotropic properties (when directedness is differential). Solid construction materials have crystal structure. Inconel 718 is characterized by faced centre cubic structure A1 (Fig.1a).

Nickel based alloys are characterized by good plasticity. This is due to the presence of large amount of planes which are close-packing with an atom which is typical for faced centre cubic structure. Nickel based alloys are less sensitive to load speed at diffident temperatures through which these alloys are characterized by smaller brittleness. Nickel based alloys are also characterized by high strength in regular conditions and elevated temperatures. Self-hardening of nickel based alloys appears as a result of thermal treatment through which small, hard and stable intermetallic phases are released. Chemical composition of Inconel 718 is presented in Tab.1.

Table 1 Chemical composition of Inconel 718
\begin{tabular}{|c|c|c|c|}
\hline $\begin{array}{c}\text { Chemical } \\
\text { composition }\end{array}$ & Max \% & $\begin{array}{c}\text { Chemical } \\
\text { composition }\end{array}$ & Max \% \\
\hline $\mathrm{Ni}+(\mathrm{Co})$ & $50-55$ & $\mathrm{Si}$ & $0.35 \mathrm{max}$ \\
\hline $\mathrm{Cr}$ & $17-21$ & $\mathrm{P}$ & $0.015 \mathrm{max}$ \\
\hline $\mathrm{Nb}+(\mathrm{Ta})$ & 1.35 & $\mathrm{~S}$ & $0.002 \mathrm{max}$ \\
\hline $\mathrm{Mo}$ & $2.8-3.3$ & $\mathrm{~B}$ & $0.006 \mathrm{max}$ \\
\hline $\mathrm{Ti}$ & $0.65-1.15$ & $\mathrm{Cu}$ & $0.30 \mathrm{max}$ \\
\hline $\mathrm{Al}$ & $0.2-0.8$ & $\mathrm{~N}$ & $0.01 \mathrm{max}$ \\
\hline $\mathrm{Co}$ & $1.00 \max$ & $\mathrm{Si}$ & $0.35 \max$ \\
\hline $\mathrm{C}$ & $0.05 \max$ & $\mathrm{Mg}$ & $0.35 \max$ \\
\hline
\end{tabular}

Chromium and silicon demonstrate increased corrosion resistance of Inconel 718. Aluminium increases creep resistance of nickel based alloys. Presence of cobalt improves their hardness and durability. These alloys retain their properties in wide range of temperatures, especially at elevated temperatures. Titanium based alloys crystalize in hexagonal close packed structure are characterized by lower plasticity. Tab. 2 represents chemical composition of titanium based alloy Ti6Al4V.

Table 2 Chemical composition of Ti6Al4V

\begin{tabular}{|c|c|c|c|}
\hline $\begin{array}{c}\text { Chemical } \\
\text { composition }\end{array}$ & Max $\%$ & $\begin{array}{c}\text { Chemical } \\
\text { composition }\end{array}$ & Max \% \\
\hline $\mathrm{Al}$ & 6,75 & $\mathrm{~N}$ & 0,05 \\
\hline $\mathrm{V}$ & 4,5 & $\mathrm{C}$ & 0,08 \\
\hline $\mathrm{Fe}$ & 0,3 & $\mathrm{H}$ & 0,015 \\
\hline $\mathrm{O}$ & 0,2 & $\mathrm{Ti}$ & the rest \\
\hline
\end{tabular}

Due to the chemical composition of Ti6Al4V they are characterized by high creep resistance, brittleness resistance and thermal stability. The most important alloying addition of Ti6Al4V is aluminium whose job is to reduce density of these alloys [2, 3]. 


\section{DEFECTS IN CRYSTAL LATTICE}

In polycrystalline materials defects occur which cause disorder in the structural periodicity. Most of physical and chemical properties depend on the type of defect that occurs in the material. The following properties are the most sensitive to defects: electrical conductivity, magnetic and optical properties. Moreover, character and amount of occurring defects may have an impact on technological process. Defects can be divided based on the size of disordered area (Tab.3). Defects which generate structure disorder in atomic scale or disorder in scale of $10^{2}-10^{4} \AA$ can be distinguished [4].

Table 3 Defects in crystalline materials [4]

\begin{tabular}{|c|c|c|}
\hline Scale of defects & Type of defects & Name of defects \\
\hline \multirow{4}{*}{ Macroscopic } & Morphological & $\begin{array}{c}\text { Cracks } \\
\text { Inclusion } \\
\text { Scratch }\end{array}$ \\
\cline { 2 - 3 } & $\begin{array}{c}\text { Mosaic } \\
\text { construction }\end{array}$ & Crystal block \\
\hline \multirow{4}{*}{$\begin{array}{c}\text { Atomic (proper } \\
\text { structural defects) }\end{array}$} & Point defects & $\begin{array}{c}\text { Vacancy } \\
\text { Interstitials atom or ion }\end{array}$ \\
\cline { 2 - 3 } & Line defects & $\begin{array}{c}\text { The edge dislocation } \\
\text { The screw dislocation } \\
\text { Partial dislocation }\end{array}$ \\
\cline { 2 - 3 } & Surface defects & $\begin{array}{c}\text { Twin boundary } \\
\text { Packing error }\end{array}$ \\
\hline Subatomic & Electron defects & $\begin{array}{c}\text { Excess electron } \\
\text { Electron hole } \\
\text { Exciton }\end{array}$ \\
\hline
\end{tabular}

\section{PROPERTIES OF SURFACE LAYER}

Milling is one of the machining methods by which desired dimensions and surface finish is achieved by gradually removing the excess material from the workpiece. Due to the machining process, properties of materials may change which substantially affects the utility properties of the workpiece. Materials' properties can be divided into: chemical, physical and technological. Among physical properties of materials the following features can be selected: melting temperature, thermal conductivity, electrical conductivity, stresses and density which influence weight of the material. Main chemical properties of materials include: corrosion resistance and heat resistance. Tensile and compressive strength, plasticity, elasticity, hardness and toughness belong to the group of mechanical properties. Hardness is a significant property of the material. The harder the material is, the higher the abrasion resistance is. Elasticity is the ability of material to recover its original shape when the force that causes deformation stops working. Elasticity is described by elastic constants: Young modulus and Poisson's ratio.

Different types of defects occur due to the way of surface layer creation. Defects occur unevenly or are partially weakened by changes induced by exploitation process e.g. during friction or caused by physicochemical phenomenon. Properties of the surface layer usually depend on the following: chemical composition; physicochemical properties of core of material, cutting parameters and on the type of machining process.

Surface layer with specific properties is always generated in the machining process. The main common feature of existing surface layer's models is zonation which is characterized by different construction and properties in different distances of physicochemical surfaces [5].

\section{IDENTIFICATION OF RESIDUAL STRESSES}

Inside of the material which is subjected to mechanical treatment structural changes occur among which changes in stress state can be distinguished. Deformations created in the workpiece can be identified to be X-ray diffraction method and stresses can be calculated by the adequate mathematical equations based on the received data. X-ray diffraction is based on the diffraction phenomenon which refers to the scattering of $\mathrm{X}$-rays which are falling on the matter. Moreover, falling $\mathrm{X}$-rays have an interference ability emitted by individual atoms.

Due to the atomics arrangement of crystalline materials, X-rays which are coherent in some directions can be intensified and others can be quenched. When waves are coherent in phase and they appear in the same directions, the intensification of rays takes place. Apart from primary rays, reflected beams (rays) occur (rays which are reflected from original direction also called diffracted rays). An angle of deflection appears between primary and diffracted beam. This angle decides about shape and size of crystal unit cells. Deflected angle always equals $2 \theta$. Intensity of diffracted beam suggests arrangement and type of atoms inside of the cell [4].

Intensification of rays diffracted from parallel planes, which belong to the same plane family $(h k l)$, occurs when the difference of their roads is equal to the integral multiple of the wavelength $(n \lambda)$ because only in this case waves can be coherent in phase. Geometrical condition of X-rays diffraction of interplanar distances $d_{h k l}$ is presented by Bragg's law in Eq. (1).

$n \lambda=2 d_{h k l} \sin \theta$

Number $n$ represents a number of wavelength located within the path representing the difference between two interfering beams and can be represented by $n=1,2,3, \ldots$ values. Diffraction phenomenon appears when the following condition is fulfilled (Eq. (2)):

$\lambda=2 d_{h k l} \sin \theta$

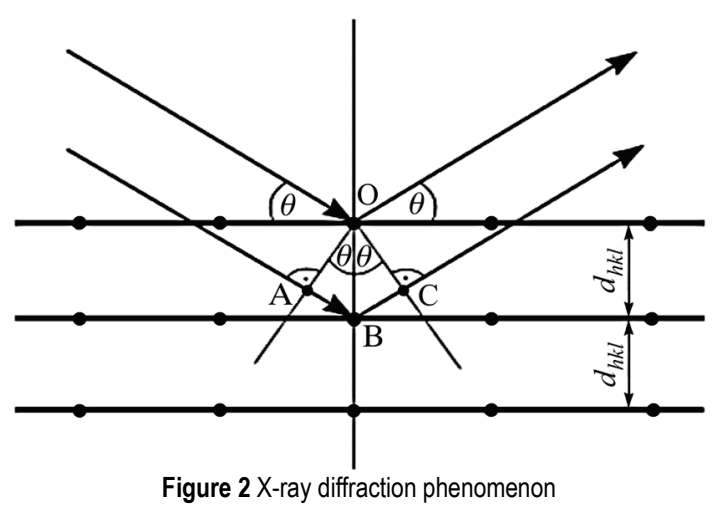


Diffraction's condition and Bragg's law are shown in Fig. 2.

\section{RESULTS FROM CARRIED OUT RESEARCH}

Research was carried out on a diffractometer (Bruker's company, Fig. 3 and Fig. 4). Residual stresses were identified in samples made out of difficult-to-cut materials: titanium based alloys Ti6Al4V and nickel based alloys Inconel 718 (described by $\mathrm{T}$ and $\mathrm{N}$ ).

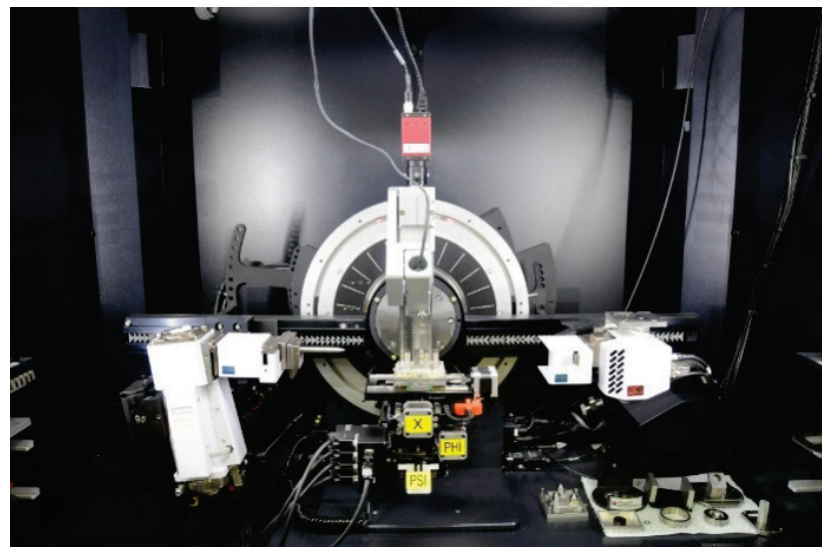

Figure 3 X-ray diffractometer

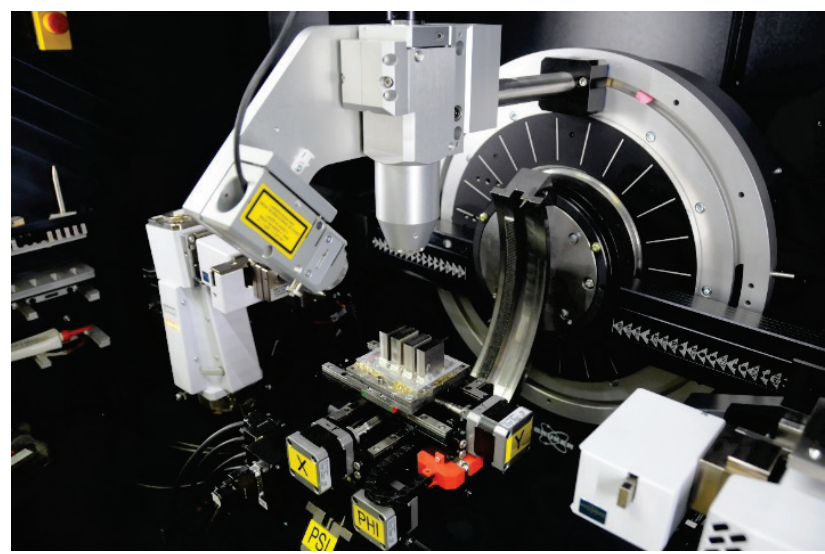

Figure 4 Localization of samples

Samples were subjected to peripheral milling (Fig. 5) under different cutting conditions that are given in Tab. 4. During machining, three different cutting parameters (cutting speed $v_{\mathrm{c}}$, feed $f$ and depth of cut $a_{\mathrm{p}}$ ) were used.

After the process of milling residual stresses were measured. Samples marked as T88 and N88 were not subjected to milling and provide a basis for comparison of identified residual stresses in particular samples.

Table 4 Cutting conditions during milling process of Ti6Al4V and Inconel 718

\begin{tabular}{|c|c|c|c|}
\hline \multicolumn{4}{|c|}{ Ti6Al4V } \\
\hline No. & $v_{\mathrm{c}} / \mathrm{m} / \mathrm{min}$ & $f / \mathrm{mm} / \mathrm{min}$ & $\mathrm{a}_{\mathrm{p}} / \mathrm{mm}$ \\
\hline T1 & 46,7 & 677 & 0,35 \\
\hline T44 & 77,5 & 823 & 0,65 \\
\hline T8 & 62,1 & 750 & 0,5 \\
\hline \multicolumn{4}{|c|}{ Inconel 718} \\
\hline No. & $v_{\mathrm{c}} / \mathrm{m} / \mathrm{min}$ & $f / \mathrm{mm} / \mathrm{min}$ & $\mathrm{a}_{\mathrm{p}} / \mathrm{mm}$ \\
\hline N1 & 46,7 & 280 & 0,35 \\
\hline N44 & 77,5 & 820 & 0,65 \\
\hline N8 & 62,1 & 550 & 0,5 \\
\hline
\end{tabular}

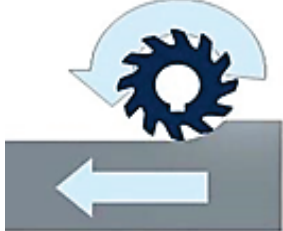

up-cut milling

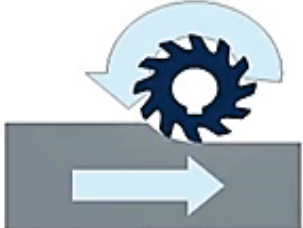

down-cut milling
$\mathrm{X}$-rays were directed perpendicularly and in parallel towards machined surface. Additionally, measurements were carried out in three and four points (marked as N8-1, N8-2, N8-3) of the sample. Received results are presented in Fig. 6 and Fig. 7.

Residual stresses in perpendicular and parallel direction to the machined surface of Inconel 718

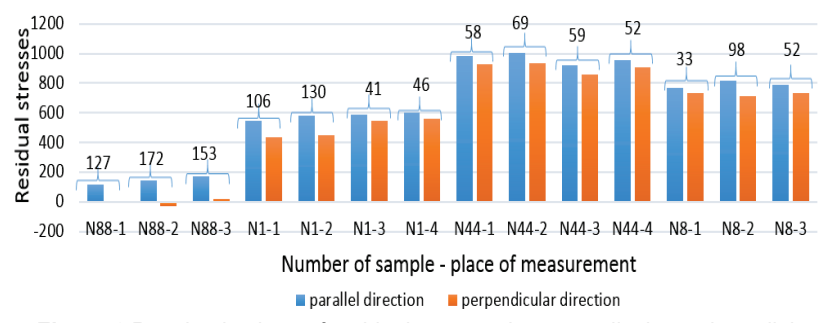

Figure 6 Received values of residual stresses in perpendicular and parallel direction to the machined surface of nickel based alloy Inconel 718

Marker labels on the graphs are the difference between stresses measured in parallel and in perpendicular direction and are provided in $\mathrm{MPa}$. Obtained values of residual stress indicate that values of residual stresses change with the change of cutting parameters. The tendency to tensile stresses in nickel based alloys can be seen. The value of tensile stresses increases with change of cutting parameters.

\section{Residual stresses in perpendicular and parallel} direction to the machined surface of Ti6Al4V

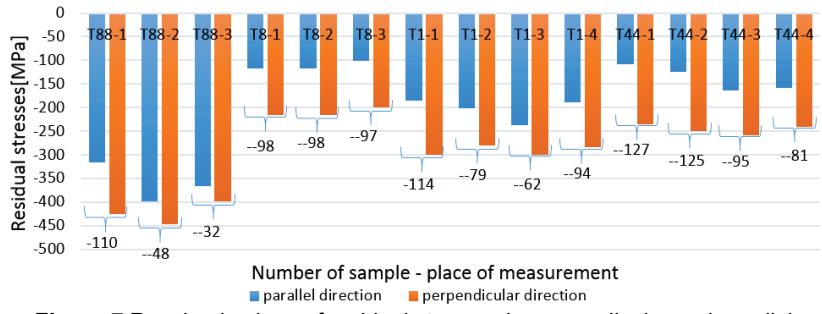

Figure 7 Received values of residual stresses in perpendicular and paralle direction to the machined surface of titanium based alloy Ti6Al4V

In case of residual stresses occurring in the elements made out of titanium based alloys, tendency to compressive stresses is observed. In case of these materials tendency to positive stresses exists which does not exceed the range of compressive stresses.

\section{CONCLUSION}

Research was carried out for three different cutting parameters (feed, cutting speed and depth of cut). It has been shown that values and type of stresses depend on cutting conditions and properties of the workpiece. 
Compressive stresses occur in titanium based alloys after milling process and tensile stresses occur in Inconel 718.

The results obtained from carried out studies indicate that during machining of samples made out of Ti6Al4V mechanical loads play a dominant role. Under the influence of cutting tool stress area is created on the machining surface which causes plastic deformation. Layers which are originally in an elastic elongation state begin to shrink as a result of cutting tool's displacement against machining surface. This leads to the occurrence of the compressive state of plastically deformed layers. Consequently, compressive residual stresses occur in the surface layer of samples made out of Ti6Al4V.

During milling of samples made out of Inconel 718 thermal loads play a dominant role. During the process of demolition of material consistency temperature field is formed in the cutting zone. Surface layer of the material heats up more than deeper zones. Consequently, compressive state occurs at the surface layer while inside of the material compressive stresses decrease and is changed into tensile stresses. As a result of displacement of the cutting tool temperature field disappears in plastically deformed upper zone of the surface layer. The upper zone is subjected to elongation by dipper zones which are originally in an elastic deformation. These zones return to their original state but plastically deformed zone is dominated by presence of tensile stresses. In order to check the reliability of obtained results further comparative study needs to be conducted with the use of one of destructive method of residual stresses measurement.

The knowledge about mechanism of residual stresses occurrence after machining can be used for planning of machining operations and creating desired state of residual stresses in surface layer.

\section{REFERENCES}

[1] Godzimirski, J. (2008). Lotnicze materiaty konstrukcyjne, Wydawnictwo Wojskowej Akademii Technicznej, Warszawa

[2] Songmei, Y., Xuebo, H., Guangyuan, Z. \& Amin, M. (2017). A novel approach of applying copper nanoparticles in minimum quantity lubrication for milling of Ti-6Al-4V. Advances in Production Engineering \& Management, 12(2), 139-150. https://doi.org/10.14743/apem2017.2.246

[3] El-Labban, H. F., Mahmoud, E. R. I. \& Al-Wadai, H. (2014). Laser cladding of Ti-6Al-4V alloy with vanadium carbide articles. Advances in Production Engineering \& Management, 9(4), pp. 159-167. http://dx.doi.org/10.14743/apem2014.4.184

[4] Bajorski, Z., Habla, H. \& Surowiec, M. (1986). Materiaty do nauki krystalografii, Państwowe Wydawnictwo Naukowe, Warszawa.

[5] Burakowski, T. (2013). Areologia - podstawy teoretyczne, Instytut Technologii Eksploatacji - Państwowy Instytut Badawczy, Radom.

[6] Wawszczak, R. (2012). Naprężenia własne w materiałach polikrystalicznych oraz ich zmienność podczas obróbki termicznej, Rozprawa doktorska, AGH, Kraków.

[7] Biel, M. (2006). Mikrostruktura i wtaściwości biomateriałów tytanowych po obróbce powierzchniowej, Rozprawa doktorska, AGH, Kraków.

[8] Krajewska, J. (2014). Wybrane problemy diagnostyki procesu obróbki materiałów trudnoskrawalnych. Oficyna
Wydawnicza Polskiego Towarzystwa Zarzadzania Produkcja w Opolu Zakopane, 749-759.

[9] Mital, D., Michalik, P., Duplak, J., Radchenko, S., Zivcak, J., Kaczmarska, B. \& Alowa Mahommed, J. A. (2016). Method for measurement of residual stresses using eddy current. Key Engineering Materials, 669, 409-416. https://doi.org/10.4028/www.scientific.net/KEM.669.409

[10] Tang, Z. T., Liu, Z. Q., Wan, Y. \& Ai, X. (2008). Study on Residual Stresses in Milling Aluminium Alloy 7050-T7451. In: Yan, X. T., Jiang, C., Eynard, B. (eds) Advanced Design and Manufacture to Gain a Competitive Edge. Springer, London. https://doi.org/10.1007/978-1-84800-241-8_18

[11] Putyra, P., Skrzypek, S., Smuk, B. \& Podsiadło, M. (2010). Analysis of residual stresses using the $\sin ^{2} \Psi$ method for $\mathrm{Al}_{2} \mathrm{O}_{3}$ materials before and after grinding and heat treatment processes. Materiaty Ceramiczne /Ceramic Materials, 62(3), 301-306.

\section{Contact information:}

Joanna KRAJEWSKA-ŚPIEWAK, PhD, Corresponding author

Cracow University of Technology,

Al. Jana Pawła II 37, 31-864 Kraków, Poland

joannakrajewska.pk@gmail.com

\section{Józef GAWLIK, Prof. Eng.}

Cracow University of Technology,

Al. Jana Pawła II 37, 31-864 Kraków, Poland

jgawlik.pk@gmail.com

\section{Witold PIEKOSZWESKI, Prof. Eng.}

Institute for Sustainable Technologies,

National Research Institute in Radom,

UI. K. Pułaskiego 6/10, 26-600 Radom, Poland

witold.piekoszewski@itee.radom.pl

\section{Krzysztof STACHURA, MSc.}

University of Technologies and Humanities in Radom,

UI. Malczewskiego 29, 26-600 Radom, Poland

stachura.kms@gmail.com 